\title{
A Local Action Plan (PAL) to Combat Desertification in Apulia Region: Functional Integration of Existing Territorial Programs
}

\author{
Claudia Trotta, Massimo Iannetta* \\ ENEA - CR Casaccia - "Sustainable Development and Innovation of Agro-industrial System" Technical Unit \\ Via Anguillarese 301, 00123 Rome, Italy
}

Received: 23 December 2009. Accepted: 25 March 2010.

\begin{abstract}
In 2006-2007, the Italian National Committee to Combat Drought and Desertification promoted the execution of local action plans in some of the Italian regions. The aims of these plans were: to carry out specific actions at a local scale; to promote the integration of local policies; to involve the local communities in proposing strategies to be adopted; to harmonize the procedures among institutions in charge of adopting the policies. In this framework, ENEA carried out an evaluation of existing policies and programs to be considered in implementing a local action plan to combat desertification in the Apulia region. The application of the environmental and socio-economic measures of the regional Rural Development Plan 2007-2013 (PSR) seemed to be an effective tool to positively influence human activities such as agriculture, breeding, and forestry, with the purpose of preserving or improving soil characteristics and overall environmental conditions, and eventually resulting in a reduction of desertification processes. Therefore, we proposed that these measures should be taken into account and effectively integrated into the Local Action Plan of the Apulia region. Additionally, we considered the four priority sectors identified by the National Action Plan (PAN) to combat drought and desertification as the guiding principles to carry out our analysis. These sectors were: Soil Protection, Sustainable Water Management, Reduction of the Impact of Productive Activities, and Territorial Equilibrium. We also included Climate Change, in consideration of the alarming and urgent role it has assumed. The desertification-prone province of Foggia was selected as a pilot area in where to evaluate the influences that PSR measures can directly or indirectly have on desertification-related factors, and identify and implement specific actions. The Provincial Coordination Territorial Plan (PTCP) of Foggia provided the basic land units for this analysis, the "land systems". These are environmentally homogeneous areas where actions should be tuned according with local characteristics. Those PSR measures that best related to actions for combating desertification were assessed by means of an evaluation matrix and analyzed for each land system context taking into account the effectiveness that they can have in relation to the afore-mentioned priority sectors of action. Such assessment was based on knowledge of the territorial phenomena, also thanks to the involvement of several local experts. The results identified measures that, if promoted and applied in each land system, would best prevent or reduce desertification in agreement with national guidelines.
\end{abstract}

Key-words: Local Action Plan, desertification, rural development plan.

\section{Analysis of the Local Action Plan (PAL) to combat desertification}

The activities implemented to carry on the PAL in the Apulia Region are described in the following three steps.

1. The identification of a pilot area and an assessment of the policy framework were the first steps for the implementation of the Lo- cal Action Plan (PAL) to combat desertification. The Foggia province, whose $90 \%$ of territory has been classified as subject to critical desertification risk (Fig. 1), was selected as pilot area. The Provincial Coordination Territorial Plan (PTCP) of Foggia provided the basic land units for this analysis, the "land systems" (Fig. 2), i.e. environmentally homogeneous areas where actions should be

\footnotetext{
* Corresponding Author: Tel.: +39 06 30483339; Fax: +39 06 30486250. E-mail address: massimo.iannetta@enea.it.
} 


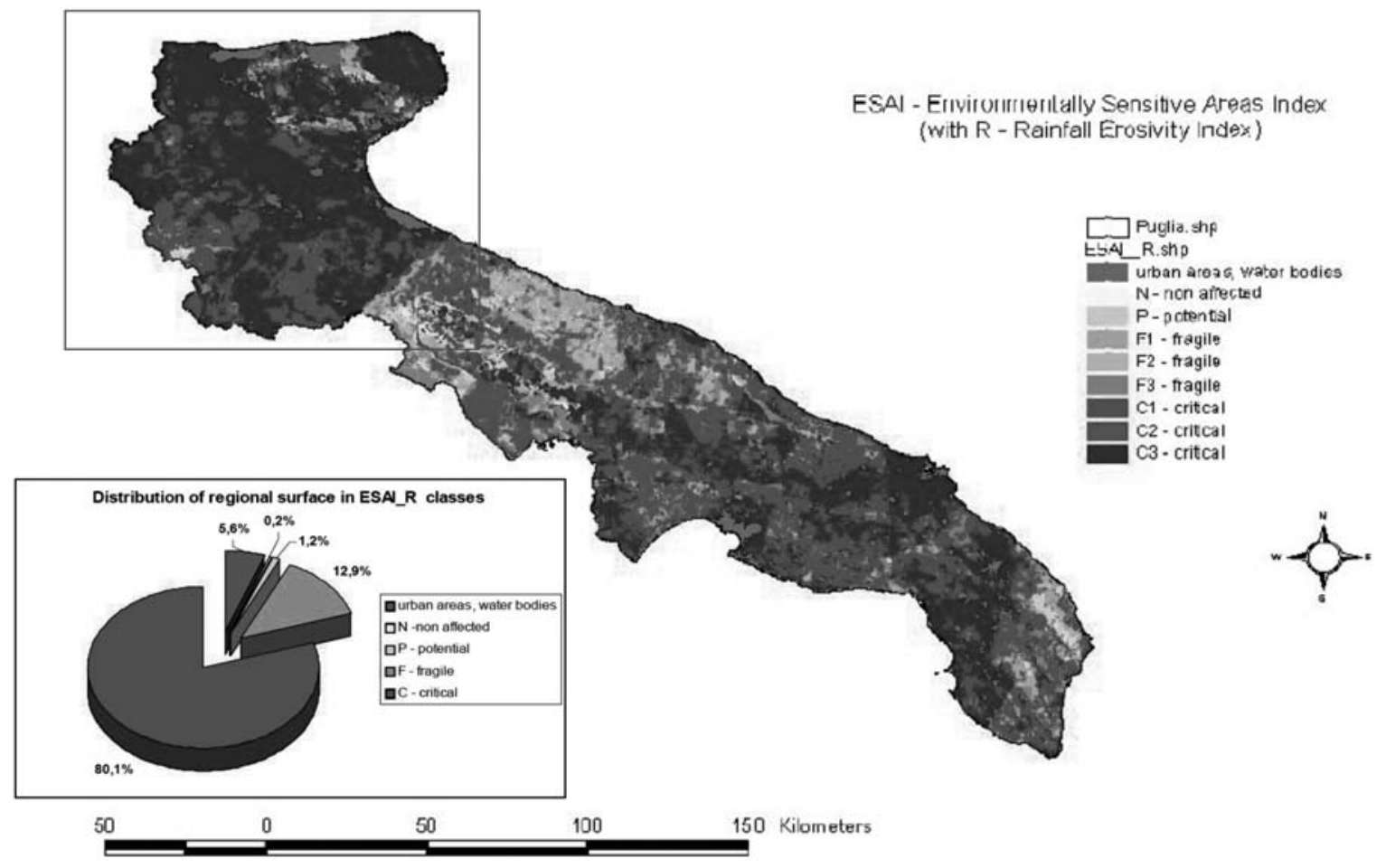

Figure 1. Desertification risk in Apulia region: modified ESAI (Trisorio-Liuzzi et al., 2005).

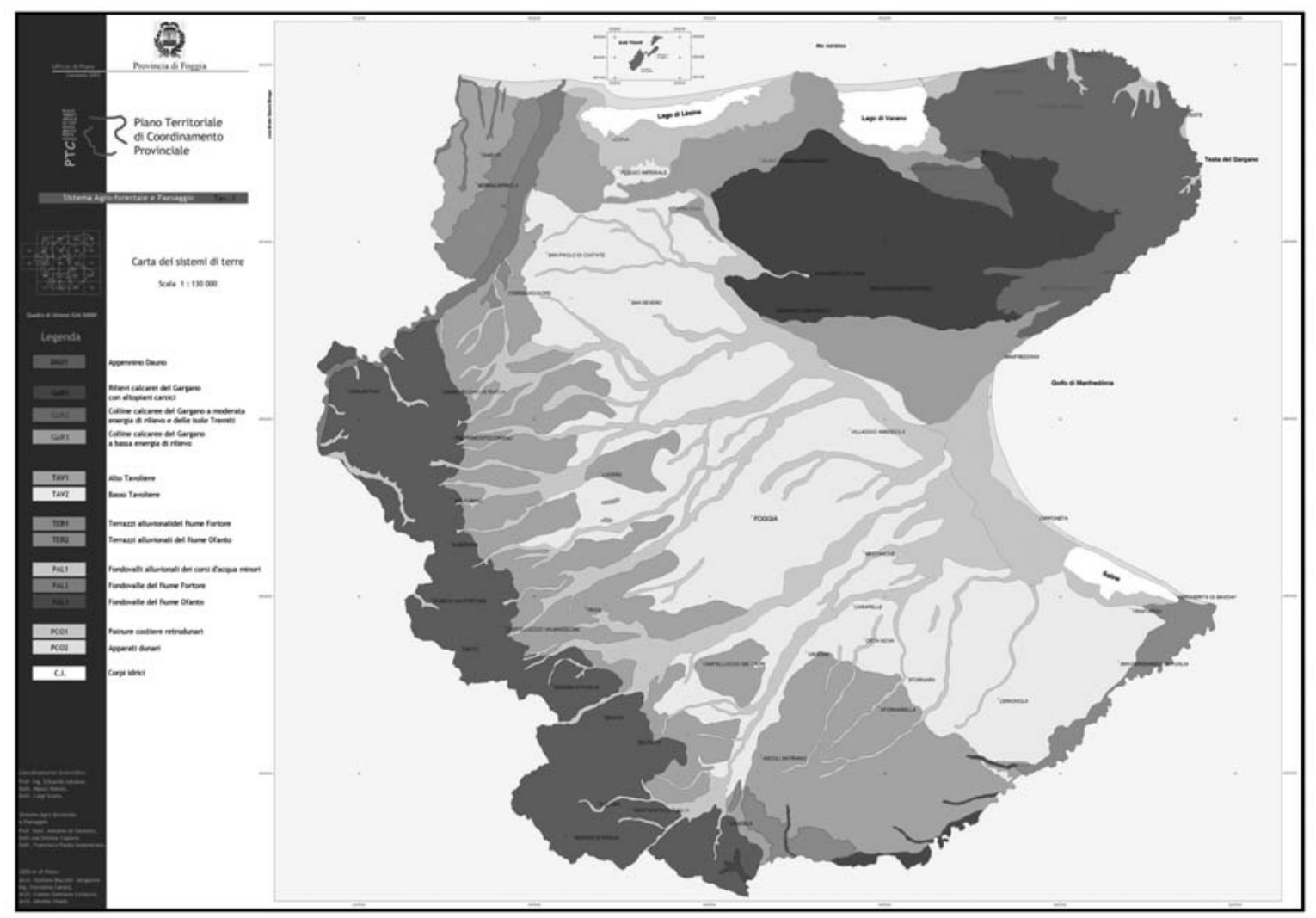

Figure 2. Foggia Province Land System Map. 


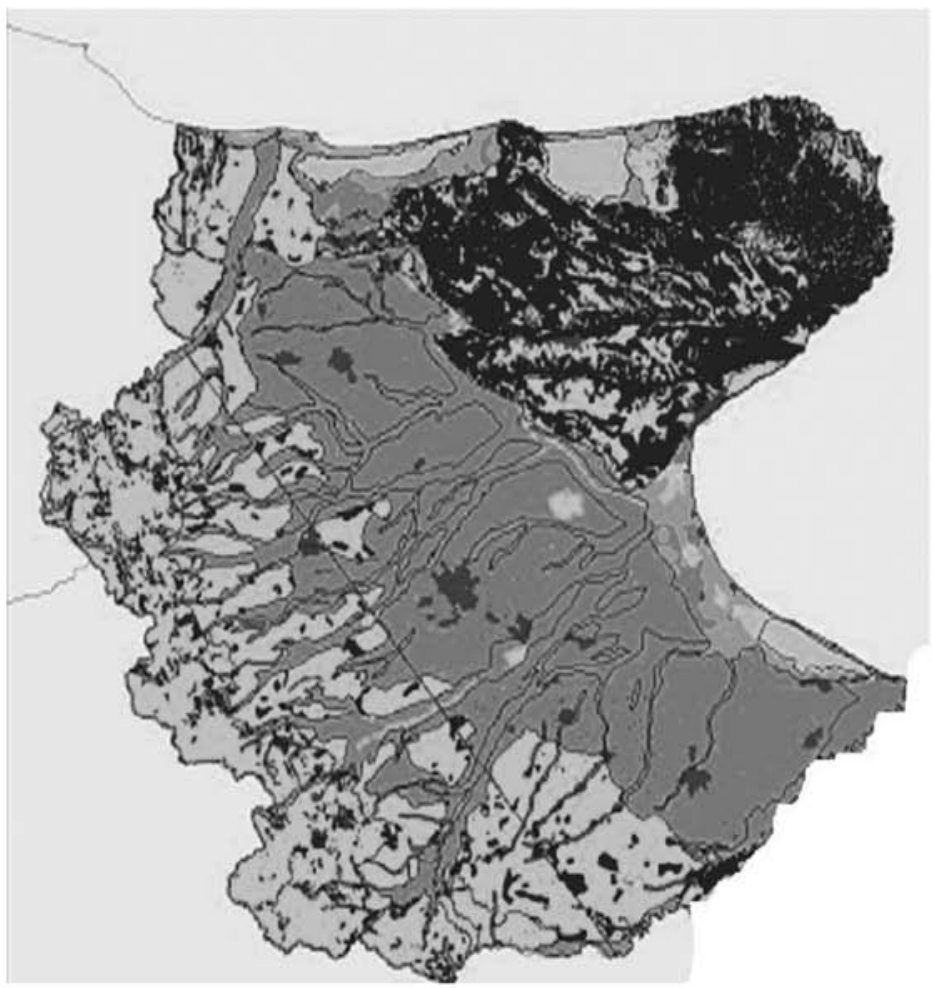

Tvnes of land degradation risk

Biological soil degradation

Chemical soil degradation

Quali-quantitive water degradation

Soil erosion

Soil sealing

Figure 3. Types of Land Degradation Risk.

tuned according with local characteristics. The PTCP had also analyzed the land use/cover changes and the land transitions, a preliminary step needed to determine and validate the natural resources degradation risk in the study area (Fig. 3). The correct application of the environmental and socioeconomic measures of the regional Rural Development Plan 2007-2013 (PSR) of Apulia Region seemed to be an effective tool to positively influence human activities such as agriculture, livestock breeding and forestry. Such measures had the potential of helping in preserving or improving soil characteristics and overall environmental conditions, eventually resulting in a reduction of desertification processes. Therefore, we proposed that these measures should be taken into account and effectively integrated into the PAL of the Apulia region. Additionally, we considered the four priority sectors identified by the PAN as the guiding principles to carry out our analysis. These sectors were: Soil Protection, Sustainable Water Management, Reduction of the Impact of Productive Activities and Territorial Balance. We also included Climate Change, in consideration of the alarming and urgent role it has assumed.

2. The PSR measures (Tab. 1) that best related to actions to combat desertification were

Table 1. List of some PSR measures evaluated.

Axe I - "Increasing of competitiveness in agriculture and forestry"

Axe II - "Environment and rural places improvement" Measure 2.1 - compensation for farmers of disadvantaged areas different from mountain areas

Measure 2.2 - compensation for Natura 2000 and 2000/60/CE directive

Measure 2.3 - agro-environmental allowances (to increase organic cultivations and avoid chemistry in agriculture) Measure 2.4 - supporting non-productive investments Measure 2.5 - afforestation of agricultural lands

Measure 2.6 - afforestation of non-agricultural lands Measure 2.7 - silvo-environmental allowances

Measure 2.8 - restoration of forestry potentiality and preventive actions

Measure 2.9 - supporting non-productive investments forestry

Axe III - "Life quality in rural areas and diversification of economic activities"

Measure 3.1 - diversification in non-agricultural activities Measure 3.5 - conservation and qualification of rural heritage 
Table 2. Example of evaluation matrix for the measure.

\begin{tabular}{|c|c|c|c|c|c|}
\hline Axe I & $\begin{array}{r}\text { Measure } 1.9 \\
\text { with the } d\end{array}$ & $\begin{array}{l}\text { improvement } \\
\text { velopment and }\end{array}$ & $\begin{array}{l}\text { nd developmen } \\
\text { adjustment of a }\end{array}$ & $\begin{array}{l}\text { of infrastruc } \\
\text { riculture anc }\end{array}$ & $\begin{array}{l}\text { s in parallel } \\
\text { riculture }\end{array}$ \\
\hline Action sector & $\begin{array}{c}\text { Soil } \\
\text { protection }\end{array}$ & $\begin{array}{l}\text { Sustainable } \\
\text { water } \\
\text { management }\end{array}$ & $\begin{array}{l}\text { Reduction of } \\
\text { the impact of } \\
\text { productive } \\
\text { activities }\end{array}$ & $\begin{array}{c}\text { Territorial } \\
\text { balance }\end{array}$ & $\begin{array}{l}\text { Climate } \\
\text { change }\end{array}$ \\
\hline High Tavoliere & ++ & ++ & $+/-$ & -- & $+/-$ \\
\hline $\begin{array}{l}\text { Gargano } \\
\text { Promontory }\end{array}$ & +++ & +++ & $+/-$ & $\begin{array}{l}-- \\
--\end{array}$ & $+/-$ \\
\hline Low Tavoliere & +++ & +++ & $+/-$ & --- & $+/-$ \\
\hline Dauno Apennine & ++ & ++ & $+/-$ & -- & $+/-$ \\
\hline $\begin{array}{l}\text { Alluvial terraces of } \\
\text { Fortore and Ofanto } \\
\text { rivers }\end{array}$ & ++ & ++ & $+/-$ & -- & $+/-$ \\
\hline Water cour se valleys & ++ & ++ & $+/-$ & -- & $+/-$ \\
\hline Coastal plains & $+/-$ & ++ & $+/-$ & -- & $+/-$ \\
\hline
\end{tabular}

assessed by means of an evaluation matrix (Tab. 2) and analysed for each land system context taking into account their effects (very positive, neutral, negative or very negative impact) in relation to the afore-mentioned priority sectors of action. The assessment was based on direct knowledge of territorial phenomena, also thanks to the involvement of several local experts. The results identified measures that, if promoted and applied in each land system, would best prevent or reduce desertification in agreement with national guidelines (Tab. 3).

3. A monitoring plan and the assessment of the implemented actions has been organized by the local office of regional agricultural services with the aim of extending this approach to further areas of Apulia. Several farms, dis- tributed throughout the province and the land systems, have been selected and will be monitored during the next years.

\section{Results}

The following results were achieved during the PAL implementation:

- analysis of the available cartographic and experimental data and calculation of the main indicators;

- characterization of the regional context and identification of areas sensitive to drought and desertification;

- work group establishment and protocol agreement ratification with the local stakeholders for the integration of local policies;

- definition and localization of the more suit-

Table 3. Synthesis of the PSR measures assessment for each land system.

\begin{tabular}{|c|c|c|c|c|c|c|c|c|c|c|c|c|}
\hline \multirow[b]{2}{*}{ Land System } & \multicolumn{6}{|c|}{ Axe 1} & \multicolumn{4}{|c|}{ Axe 2} & Axe 3 & \\
\hline & 122 & & 45 & 67 & 89 & 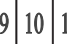 & 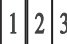 & $3 \mid 4$ & 56 & \begin{tabular}{l|l|l|l|}
7 & 8 & 9
\end{tabular} & 15 & \\
\hline High Tavoliere & & & & & & & & & & & & \\
\hline Gargano promontory & & & & & & & & & & & & Mostly positive \\
\hline Dauno subAppennine & & & & & & & & & & & & Mostly moderately positive \\
\hline Low Tavoliere & & & & & & & & & & & & Mostly negative \\
\hline Alluvial terraces of Fortore and Ofanto rivers & & & & & & & & & & & & \\
\hline Watercourse valleys & & & & & & & & & & & & Mostly not intluent \\
\hline Coastal plains & & & & & & & & & & & & Not applicable \\
\hline
\end{tabular}


able interventions to combat drought and desertification;

- formulation of a monitoring and evaluation plan;

- involvement of local communities in the process;

- partial harmonization of the procedures adopted by the different institutions in order to integrate the guidelines used in combating desertification.

\section{Conclusion}

The European Structural and Cohesion Funds on the Rural Development Plan (PSR) and Regional Operative Plan (POR) 2007-2013 provide an opportunity to implement policies to combat desertification, especially considering the lack of specifically targeted financial resources. In this context, it is important to highlight the time shift between the formulation of PAL and the actual funding of PSR. As a consequence, any eventual implication and impact will only be observable in the coming years.

The selective funding od specific measures seems advisable. A particular attention should be paid to environmental aspects when promoting actions that are likely to have long-lasting impacts on fragile territories.

We identified a selection of representative farms for each land system that can be used to monitor the effectiveness of the PSR measures that the Apulia region will fund. The focus will be on the evaluation of the environmental and economic success that the adopted measures have in terms of contrasting, mitigating and/or adaptating to desertification processes.

In conclusion, we would like to stress how putting together and integrating both administrative (Foggia province) and territorial (land systems) aspects is an approach of great importance to combat desertification since it allows the implementation of a PAL more tightly connected to the territorial context and to the land management program of the Province.

\section{Lessons learned}

The involvement of local citizens, stakeholders and administrations does not necessarily promote success, because of the low political sensitiveness and poor Gov- ernance beyond the social and economic aspects linked to farm management. In this experience, the integration of the "combating desertification" guidelines in the territorial management plan was carried out.

\section{References}

Colonna N., Lupia F., Iannetta M. 2008. Expert knowledge-based methodology for land degradation risk evaluation. In: $10^{\text {th }}$ Congress of the European Society for Agronomy on "Multi-functional Agricolture: Agriculture as a Resource for Energy and Environmental Preservation". Bologna, Italy, 15-19 September 2008, Rossi Pisa P. (ed.). Italian Journal of Agronomy, Vol. 3, N. 3, supplement July-September 2008.

Colonna N., Lupia F., Iannetta M. 2008. Severe environmental constraints for Mediterranean agricolture and new options for water and soil resources management. In: Zdruli P., Costantini E. (eds.): $5^{\text {th }}$ International Conference on Land Degradation. Valenzano (Bari), Italy, 18-22 September 2008, ISBN 2-853 52-399-3.

Debolini M., Galli M., Bonari E. 2008. Agro-environmental risk analysis at landscape scale: limits for a sustainable land management. In: Rossi Pisa P. (ed.): ESA2008: Multifunctional Agriculture. $10^{\text {th }}$ Congress of the European Society of Agronomy, Bologna, Vol 3, N. 3 suppl. Italian J. Agronomy.

FAO 1995. Planning for sustainable use of land resources. Toward a new approach. Land and Water Bulletin, 2. Roma.

Gassman P.W., Reyes M.R., Green C.H., Aronold J.G. 2009. The soil and water assessment tool: historical development, applications and future research directions. In: Arnold J. et al. (eds.): Soil and Water Assessment Tool (SWAT), Global applications. World Association of Soil and Water Conservation (WASWC) Special pubblications N. 4, 25-96.

Iannetta M. 2007. Analisi degli aspetti economici ed ambientali legati alla desertificazione. Capitolo 6 del volume: Uso irriguo dell'acqua e principali implicazioni di natura ambientale. A cura di INEA, novembre 2007, ISBN 978-88-8145-084-4.

Iannetta M. 2007. Interazioni tra cambiamenti climatici e desertificazione. Accademia Nazionale delle Scienze detta dei XL. Memorie di Scienze Fisiche e Naturali. $125^{\circ}$ (2007), Vol. XXXI, P. II, t. I, 277-295.

Iannetta M. 2007. RIADE Project: Severe environmental constraints for Mediterranean agricolture and new options for water and soil resources management. Proceedings of the UE INCO WUEMED Workshop on "Improving water use efficiency in Mediterranean agriculture: what limits the adoption of new technologies?". CNR, 29-30 settembre 2005, Roma, Italy. Publisher: Edizioni Avenue media, 2007, ISBN 97888-86817-39-4.

Iannetta M. 2008. Analisi degli aspetti economici ed ambientali legati alla desertificazione. Capitolo 3 del vol- 
ume: Analisi degli aspetti economici ed ambientali legati alla desertificazione. A cura di INEA, novembre 2008, ISBN 978-88-8145-119-7.

Iannetta M., Colonna N. 2009. Salinisation in the Mediterranean context. Booklet in the framework of the VI Framework Programma Priorità 1.1.6.3 Global Change and Ecosystems, EU SSA Lucinda Project.

Kersten G.E., Gordon L.O. 1999. DSS application areas. In: Kersten G.E., Zbigniew M., Yeh A.G.O. (eds.): Decision Support Systems for Sustainable Development. A Resource Book of Methods and Applications. Springer, Berlin Heidelberg New York, 440 pp.

Mysiak J. 2005. Decision support Systems for integrated water resurces management value and success factors. Paper presented at the International Symposium on Environmental Software Systems, Sesimbra, Portugal, 24-27 May, 2005.
Rais M., Gamed S., Craswell E.T., Sajjapongse A., Bechstedt H.D. 1999. Decision support system for sustainable land management. In: Kersten G.E., Zbigniew M., Yeh A.G.O. (eds.): Decision Support Systems for Sustainable Development. A Resource Book of Methods and Applications. Springer, Berlin Heidelberg New York, 440 pp.

Trisorio-Liuzzi G., Ladisa G., Todorovic M. 2005. Identification of areas sensitive to desertification in semiarid Mediterranean environments: the case study of the Apulia region (southern Italy). International Conference on: Water, Land and Food security in Arid and Semi-Arid Regions, Bari 6-11 September 2005, 369-398.

Van Buuren J., Engelen G., Van de Ven K. 2002. The DSS WadBOS and EU Policies Implementation, Proceedings of the Conference Littoral 2002, The Changing Coast, Porto, Portugal, 533-540. 